\title{
Exergy Rate Profile of Multicomponent Distillation System
}

\author{
http://dx.doi.org/10.3991/ijes.v4i2.5710 \\ K. Adewale Adesina ${ }^{1}$ and C. Abiodun Popoola ${ }^{2}$ \\ ${ }^{1}$ Eastern Mediterranean University, Famagusta, North Cyprus, Turkey \\ ${ }^{2}$ Federal University Wukari, Taraba State, Nigeria
}

\begin{abstract}
Exergy rate profiles, exergetic efficiency and irreversibility were used to examine the driving forces in multicomponent distillation system with the view to identifying feasible and efficient operating parameters. The mixture used comprised of $5 \%$ propane, $15 \%$ iso-butane, $25 \% \mathrm{n}$ butane, $20 \%$ iso-pentane and $35 \%$ n-pentane. Operating variables were feed temperature $\left(-30{ }^{\circ} \mathrm{C}\right.$ and $\left.-80{ }^{\circ} \mathrm{C}\right)$, pressure $(800 \mathrm{kPa}$ and $1200 \mathrm{kPa})$, and reflux-ratio (2 and 6). Stage-by-stage system exergy analysis was estimated. Column profiles of base case $-30{ }^{\circ} \mathrm{C},-80^{\circ} \mathrm{C},-30{ }^{\circ} \mathrm{C}$-reflus ratio $6,-80^{\circ} \mathrm{C}$ reflux ratio 6 and base case reflux ratio 6 did not crossed thus are thermodynamically feasible. Base case $-\mathbf{3 0}$ ${ }^{\circ} \mathrm{C}$-reflux ratio $2,-80{ }^{\circ} \mathrm{C}$-reflux ratio 2 , and base case-reflux ratio 2 were crossed and constricted and are infeasible. Base case results gave efficiency of $81.7 \%$ at depropanizer and $\mathbf{6 5 . 2 \%}$ at debutanizer. Base cases sensitivity results with -30 ${ }^{\circ} \mathrm{C},-80{ }^{\circ} \mathrm{C}$ and reflux ratio 6 , efficiency range $57.40-70 \%$ and $65.20 \%-54.90 \%$ for depropanizer and debutanizer respectively. Spitted cases gave $81.7 \%$ and $62.20 \%$ with more scatter profiles. Splitted feed base case $-30{ }^{\circ} \mathrm{C}$ design gave the lowest overall system exergy loss rate of $1.12 \mathrm{E}+6$ and efficiency of $95.70 \%$. Design feasible parameters, system efficiency and irreversibility which form basis for system improvement can be identified and evaluated.
\end{abstract}

Index Terms-exergy, rate-profile, driving-forces, irreversibility, multicomponent-distillation

\section{INTRODUCTION}

Distillation is the mostly used separation technique in chemical and petrochemical industries and its increasing usage is accompanied by a increasingly large consumption of energy [8]. Distillation is known for the separation of about $95 \%$ of most fluids and that around 3\% of the total energy consumption in the world is used in distillation units [7]. According to recent estimates, $40 \%$ of energy used in refinery and other continuous chemical processes are consumed by distillation [19]. Therefore designing energy efficient distillation processes had been an important issues discussed in various literatures [14,9]. These analyses have focused only on energy and ignored the quality of energy. The energy demand in distillation system is an increasingly inevitable process performance factor, due to the increasing pressure to save energy.

Estimation of the minimum energy needed by different distillation systems can offer some early evaluation tool for comparing various efficiencies thereby alternative cab efficiently determined. Generally in distillation, energy input at the reboiler is used to evaporate a liquid mixture and is lost when liquefying the vapour flow at the condenser to obtain a reflux liquid flow. Conversely, energy recovered at the condenser cannot be used to heat other flows in the same distillation column due to the fact that temperature of the cooling medium is usually much lower than that of the column flows. Researchers having been instigated by the large energy demand, have developed new sequences that can enhance savings in both energy and capital costs.

One of such options was the use of interconnected distillation systems, commonly referred to as Thermally Coupled Distillation Sequences (TCDS). TCDS have been designed more robustly for the separation of threecomponent mixtures. TCDS with a side rectifier or with a side stripper, and the fully integrated distillation column (or Petlyuk system) have been shown to provide important energy savings with respect to use of conventional distillation sequences $[1,10,11,12,13,23]$. A few attempts have been devised to extend this concepts to four or five component mixtures, either by conceptual arrangements or on shortcut methods [4,21].

[3] have shown a more formal design strategy for two types of thermally coupled systems for four-component mixtures, one with a side rectifier and a side stripper (TCDS-SR/SS) and the other one based on an extension of the Petlyuk system (TCDS-PR). Their analysis showed how a design for each integrated sequence can be determined from the conventional tray structure of a distillation sequence, and how such a design can be optimized for optimum energy consumption.

Tray distillation is most commonly modelled by assuming that equilibrium is established between the vapour and the liquid at the outlets of each tray in the column. However, in reality equilibrium is not attained. The first attempt is to account for the irreversibility in the process due to tray efficiencies. The Murphree efficiency measures to which degree equilibrium is reached [15]. Exergy analysis has been used successfully to examine the thermodynamic efficiency of distillation columns $[27,18]$. Exergy is a thermodynamic property that measure the quality of energy contained in a substance and of its departure in temperature, pressure and composition from the environmental conditions. This consequently allow consideration in an integral way energetic, economic and ecological aspect in analyzing industrial processes [20]. Hence going a step further, to evaluate the quality of energy lost via exergy analysis is an efficient technique for reducing inefficiencies. [2] published a thermodynamic analysis of crude oil distillation systems which includes aspects like energy and exergy analysis, performance evaluation and system optimization.

A careful evaluation of process and plant design using exergy analysis provides platform for identification and quantification of the sources of inefficiencies or process 
irreversibility-related losses. [26] have shown that large savings could be obtained if high quality energy can be reduced. Moreover, the use of irreversible thermodynamic principles in distillation process is still under development [20]. Results of exergy and exergoeconomic analysis had been presented and explained by [16] for industrial processes. However, traditional exergy analysis has focused on the overall thermodynamic efficiency of separation and the relation of spent work (utility consumption) to the ideal work required for the separation. Very little information about how to proceed to optimize the column is available to engineers. Other recent works in the application of exergy analysis to the optimization of distillation columns considers the column as a reversible process. From [6] the resulting temperature-enthalpy profile permit the engineer to identify useful modifications to enhance the thermal efficiency of the column, hence better heat integration in the process is achieved. However, the assumption of reversibility presents some limitations for the application of this methodology to multicomponent systems [24]. Several attempts had been made by various researchers to introduce diagrammatic methods that could aid in the design and retrofit of energy efficient distillation processes $[22,17,25,6,5]$. Much consideration has not been given to multicomponent distillation systems. The aim of the research is to develop a method of using exergy analysis to generate exergetic driving forces in columns of multicomponent distillation system. This work deals with a study of separation into components mixture comprising five components - $5 \%$ propane, $15 \%$ iso-butane, $25 \%$ nbutane, $20 \%$ iso-pentane and 35\% n-pentane and presents a stage exergy rate diagrams (profiles) with the view of determining feasible and efficient multicomponent distillation system.

\section{Methodology}

\section{A. Model Simulation and Data Extraction}

The distillation separation of the mixture into pure components was carried out using Hyprotech System Simulator (HYSYS vs. 3.2). Four columns were selected in series with the bottom product of one serving as the inlet feed of the next. The columns are named Depropanizer, Debutanizer, Butane splitter and Pentane splitter sequentially. The specifications of the first column of the base case include feed temperature of $-50{ }^{\circ} \mathrm{C}$, feed pressure of $1000 \mathrm{kPa}$, and reflux ratio of 4 . The model was for a total condenser. The simulation was carried out with the initial specifications where temperature, pressure, specific enthalpy, and specific entropy and flow rates for column streams and the tray by tray compositions were obtained. The specific enthalpy and entropy for the tray by tray vapour and liquid phase at reference (environmental conditions) temperature of $293 \mathrm{~K}$ and pressure of $101.3 \mathrm{kPa}$ was computed. The simulation is for total condenser.

\section{B. Exergy Calculation}

The exergy balance for open systems at steady state used was given by Jean-Francois et al (2008) as;

$$
\begin{aligned}
& E x_{P H}=\left(H-T_{0} S\right)-\left(H_{0}-T_{0} S_{0}\right) \\
& E x_{c h, i}=E x_{c h, i}^{0}+R T_{0} \ln x_{i}
\end{aligned}
$$

$$
\begin{aligned}
& E x_{\text {Total }}=E x_{P H}+E x_{C H}=\left[\left(\left(H-T_{0} S\right)-\right.\right. \\
& \left.\left.\left(H_{0}-T_{o} S_{0}\right)+\left(\tilde{b}_{c h, i}^{o}+R T_{0} \ln x_{i}\right)\right)\right]
\end{aligned}
$$

Tray by tray irreversibility was obtained by

$$
\begin{aligned}
& I=L_{j-1} * E x_{j-1}^{L}+V_{j+1} * E x_{j+1}^{V} F_{j} * E x_{j}^{F}+ \\
& E x_{Q i}-\left(L_{j}+M_{j}\right) * E x_{j}^{L}-\left(V_{j}+U_{j}\right) * E x_{j}^{V}
\end{aligned}
$$

The first law (energy) and second law (exergy) efficiency are expressed by the equations

$$
\begin{aligned}
& \psi=\frac{\sum E x_{q}}{\sum E x_{i}} \\
& \eta=\frac{\sum \vec{E}}{\sum \vec{E}}
\end{aligned}
$$

the exergetic efficiency for a real column is written:

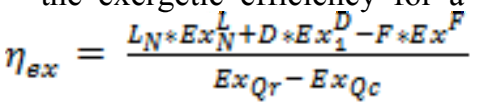

Application of equation (3.7), (3.8), (3.9), and (3.10) to the multicomponent distillation process considered in this study gave exergy efficiency and irreversibility equations;

$$
\begin{aligned}
& \psi=\frac{E x_{\text {distillate }}+E x_{\text {bottom }}+\left(1-\frac{T_{0}}{T_{\text {cond }}}\right) Q_{\text {cond }}}{E x_{f e c d}+\left(1-\frac{T_{0}}{T_{\text {reboiler }}}\right) Q_{\text {reboiler }}} \\
& I=\left(E x_{\text {feed }}+\left(1-\frac{T_{0}}{T_{\text {reboiler }}}\right) Q_{\text {reboiler }}\right)- \\
& \dot{E} x_{\text {distillate }}+E x_{\text {bottom }}+\left(1-\frac{\tau_{0}}{T_{\text {cond }}}\right) Q_{\text {cond }}
\end{aligned}
$$

where

$$
\begin{aligned}
& T_{\text {Cond }}=T_{\text {distillate }}-T_{\text {Cond diff }} \\
& T_{\text {Cond diff }}=\frac{T_{\text {cooling water in }}+T_{\text {cooling water out }}}{2} \\
& T_{\text {reboiler }}=T_{\text {distillate }}-T_{\text {reboiler diff }} \\
& T_{\text {reboiler diff }}=\frac{T_{\text {cooling water in }}+T_{\text {cooling water out }}}{2}
\end{aligned}
$$

\section{Stage Exergy Rate Diagrams}

At every stage of the distillation column, the liquid and the vapour enthalpy and exergy rate values were calculated. The rate diagrams were then generated by plot of exergy rate of the tray by tray liquid and vapor phases versus tray number. Columns exergetic driving forces was evaluated from the exergy rate profiles. Exergetic efficiency and irreversibility was also obtained and was used to determine exergetic driving forces which help to identify feasible and efficient system. Sensitivity analysis was carried out to identify the effect of variation in the operating parameters on the systems. The operating variables considered were feed temperature and pressure, and reflux-ratio. The temperature range considered was $-30{ }^{\circ} \mathrm{C}$ and $-80{ }^{\circ} \mathrm{C}$, pressure was $800 \mathrm{kPa}$ and $1200 \mathrm{kPa}$ and reflux ratio considered was 2 and 6 . Single and $50 \%$ splitted feed variation was also considered. 


\section{RESUlTS AND DisCUSSIONS}

In the first part, converged simulation results show that the model used were perfectly. Fig. 1 give the process flow model sequence for single feed system and Fig. 2 gives the process flow model sequence for splitted feed system. The Depropanizer consist of 55 trays with feed tray on 19. Debutanizer consist of 62 trays with feed tray was on tray 31 . The profiles of component composition versus tray number for the separation obtained are given in Fig. 3 and Fig. 4. The results also show that the composition of propane was vaporized at the feed inlet position located on tray 19. Fig. 4 show that iso-butane and nbutane was vaporized on the feed location and was separated to the top of the column as distillate leaving isopentane and n-pentane as liquid to the bottom of the column. Iso-butane and n-butane was separated by butane splitter component. Similarly, iso-pentane and n-pentane was separated by pentane component splitter.

The exergy rate diagram gives a pictorial representation of the happening within the column as regards the exergy profile. Specific enthalpy diagram as used by [17] gave heat and mass transfer effect in the distillation of a binary mixture but the profiles as presented in this study are for the case of total enthalpy which is all encompassing. The liquid and vapour profiles for each stage of the column reveals the driving force within the column and gives insight into the feasibility of a given operation for some set of operating conditions. The exergy rate diagram has the added advantage of determining the feasibility of not only binary columns but multicomponent columns as well. This research gives credence to this. For feasible design, the profiles are not expected to cross nor be constricted. This is because their crossing will amount to reversal of driving force within the column and hence make such design infeasible. Constriction situation is a case where the liquid and vapour lines do not cross but give extremely close profile. Constriction cases though feasible are undesired because such condition renders the design inefficient in terms of energy usage.

Fig. 5 and 6 shows the exergy rate diagrams for the columns of the base case design. The exergy profiles did not crossed showing feasible thermodynamic system with feasible process parameters. The base case design with splitted feed exergy profiles neither cross nor constricted as shown in Fig. 7 - 8. Here the liquid and vapour profiles are well spaced and scattered. Therefore operating the distillation system at the specified conditions with splitted feed is thermodynamically feasible.

Exergy profiles for sensitivity analysis were presented in Fig. 9 - 27. Profiles base case $-30{ }^{\circ} \mathrm{C},-80{ }^{\circ} \mathrm{C},-30{ }^{\circ} \mathrm{C}$ Reflus ratio $6,-80{ }^{\circ} \mathrm{C}$-Reflux ratio 6 and base case-Reflux ratio 6 were not crossed. Profiles of base case $-30{ }^{\circ} \mathrm{C}$ Reflux ratio $2,-80{ }^{\circ} \mathrm{C}$. Reflux ratio 2 , and base caseReflux ratio 2 gave crossing in their depropanizer. The columns and systems exergetic efficiency and their corresponding irreversibilities (exergy loss rate) systems are shown in Table 1 and Table 2. Base cases results gave an exergy efficiency of $81.7 \%$ at depropanizer and $65.2 \%$ at debutanizer. Base cases sensitivity results with $-30^{\circ} \mathrm{C}$, $80^{\circ} \mathrm{C}$ and reflux ratio 6 , efficiency range $57.40-70 \%$ and $65.20 \%-54.90 \%$ for depropanizer and debutanizer respectively. Spitted feed base case gave same exergy efficiency range of $81.7 \%$ and $62.20 \%$ when compared respectively with depropanizer and debutanizer of base

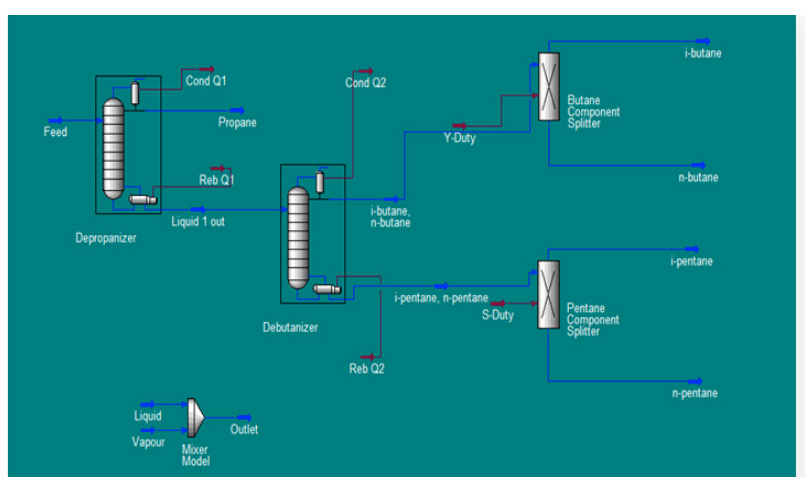

Figure 1. Process flow diagram for single feed multicomponent

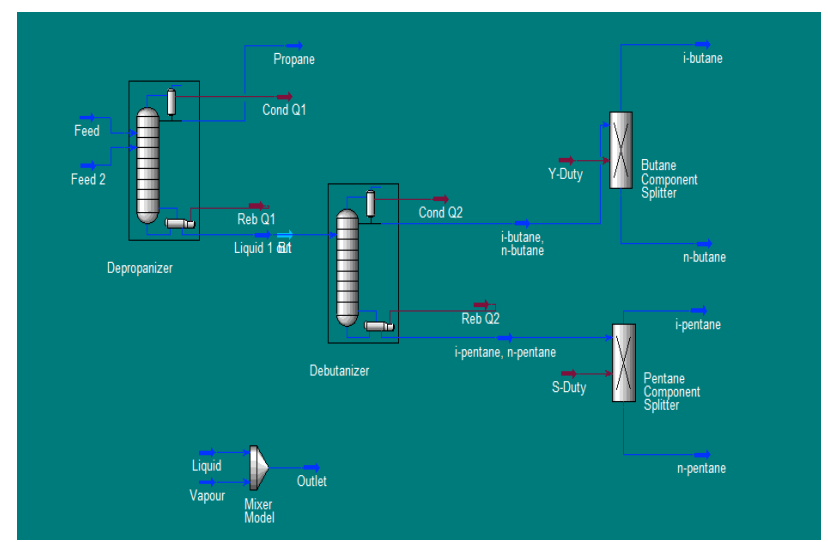

Figure 2. process flow diagram for splitted feed multicomponent system.

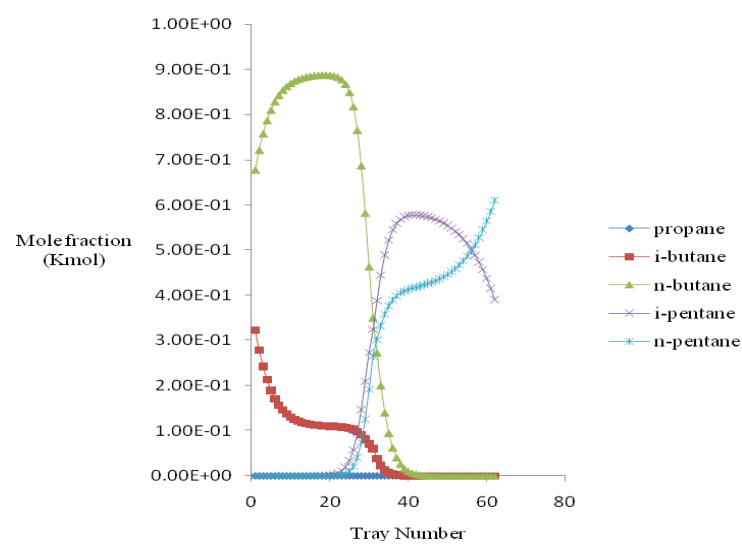

Figure 3. Molar Composition of Depropanizer of the Base Case

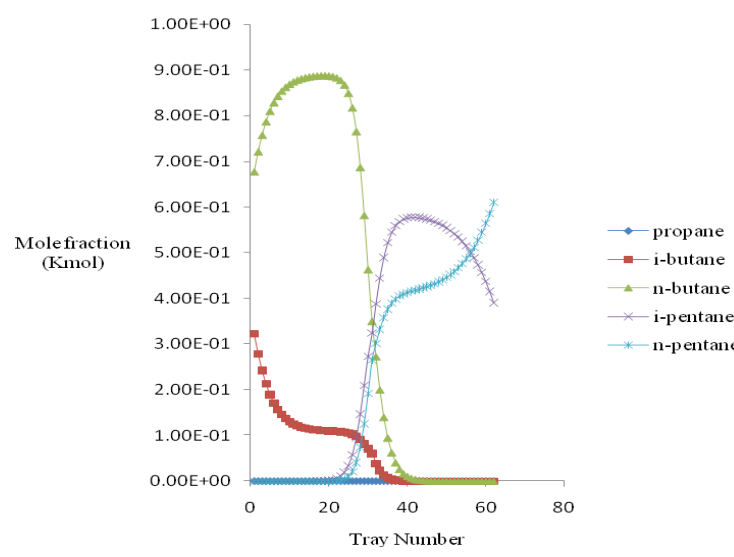

Figure 4. Molar Composition of Debutanizer of the Base Case 
PAPER

EXERGy RATE Profile of MulticomPonent Distillation SySTEM

cases. $800 \mathrm{kPa}$ case gave $82.1 \%$ and $62.5 \%$ at depropanizer and debutanizer respectively. $1200 \mathrm{kPa}$ case gave much lower exergy efficiency $0.66 \%$ and $0.65 \%$ at depropanizer and debutanizer respectively which do not compare well with the efficiencies given by the base cases, splitted feed cases and $800 \mathrm{kPa}$ cases.

This shows that operating this multicomponent distillation system at feed pressure of $1200 \mathrm{kPa}$ will be grossly inefficient and unrealistic despite the feasible exergy rate diagram. Therefore this confirm the need to supplement the second law efficiency calculation with the exergy rate diagram to determine the actual feasible operations and design. By overall system exergy efficiency, splitted base Case $\left(-30{ }^{\circ} \mathrm{C}-1000 \mathrm{kPa}\right)$ gave better efficiency of $97.99 \%$ over other base cases $-30{ }^{\circ} \mathrm{C}$ of $95.70 \%$. Exergy loss rate (irreversibility) indicated that base Cases $\left(-30{ }^{\circ} \mathrm{C}-1000\right.$ $\mathrm{kPa}$ ) gave lower overall value of $1.51 \mathrm{E}+06$. Multiple (splitted) feed for splitted base Case $\left(-30{ }^{\circ} \mathrm{C}-1000 \mathrm{kPa}\right.$ gave an enhance exergetic efficiencies of $97.99 \%$ and much lower exergy loss (irreversibilities) of $1.12 \mathrm{E}+06$.

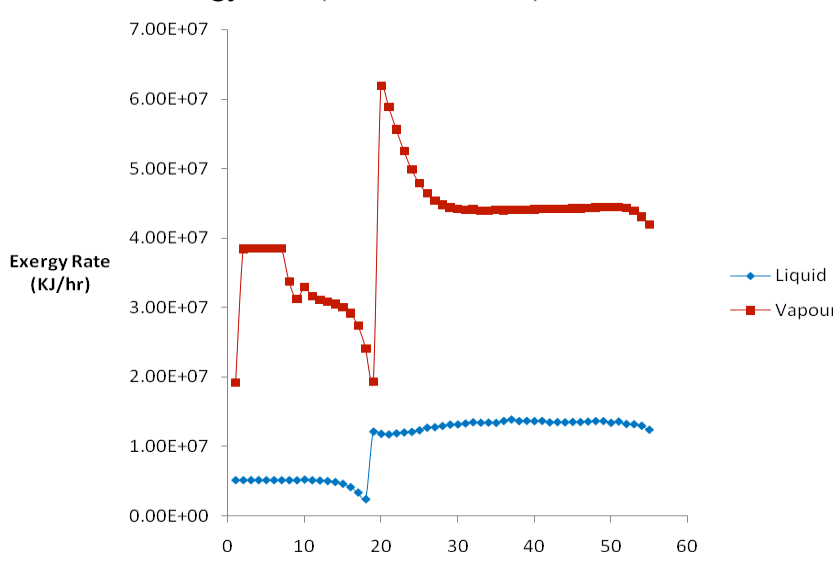

Figure 5. Profile of exergy rate versus tray number for the depropanizer of the Base Case

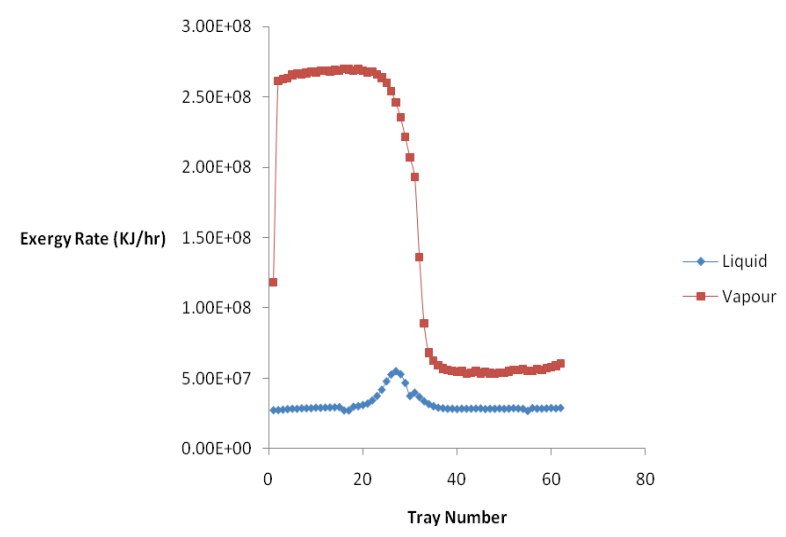

Figure 6. Profile of exergy rate versus tray number the for debutanizer of the Base Case

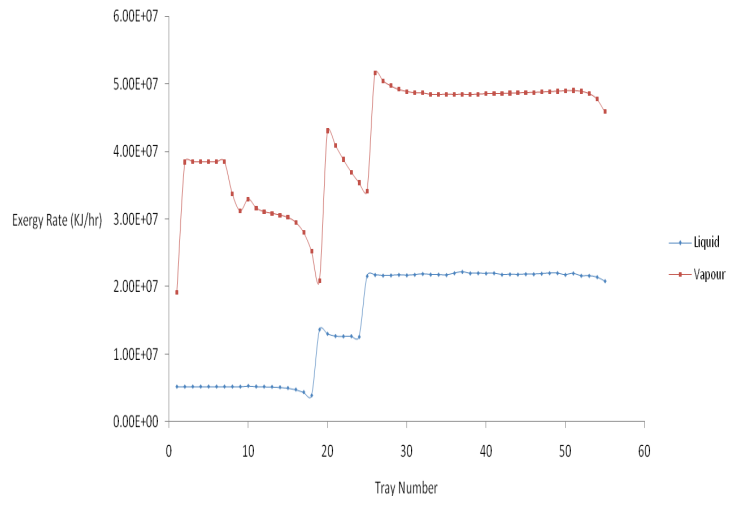

Figure 7. Profile of exergy rate versus tray number the for Depropanizer of the Base Case multiple feed

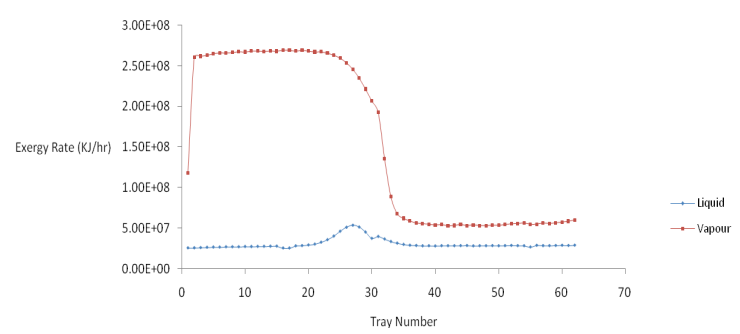

Figure 8. Profile of enthalpy rate versus tray number the for Debutanizer of the Base Case multiple feed

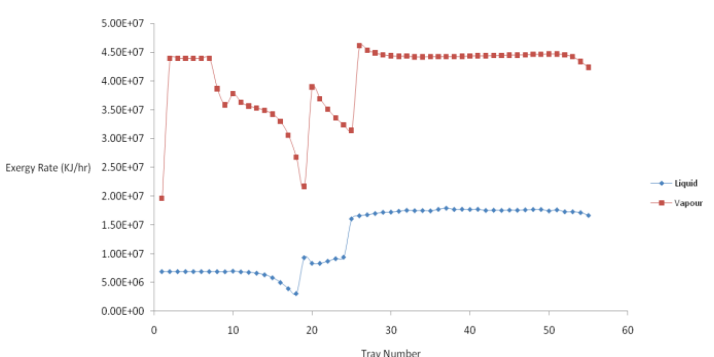

Figure 9. Profile of exergy rate versus tray number for Depropanizer of base case, $30^{\circ} \mathrm{C}$

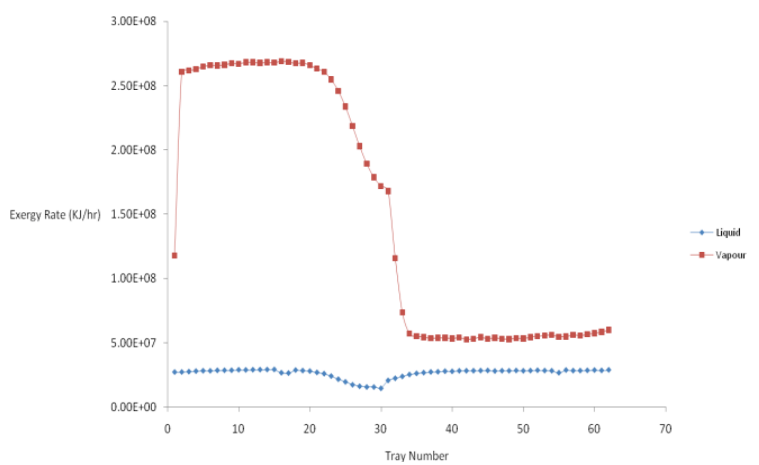

Figure 10. Profile of exergy rate versus tray number for Debutanizer of base case, $30^{\circ} \mathrm{C}$ 
PAPER

EXergy RAte Profile of Multicomponent Distillation System

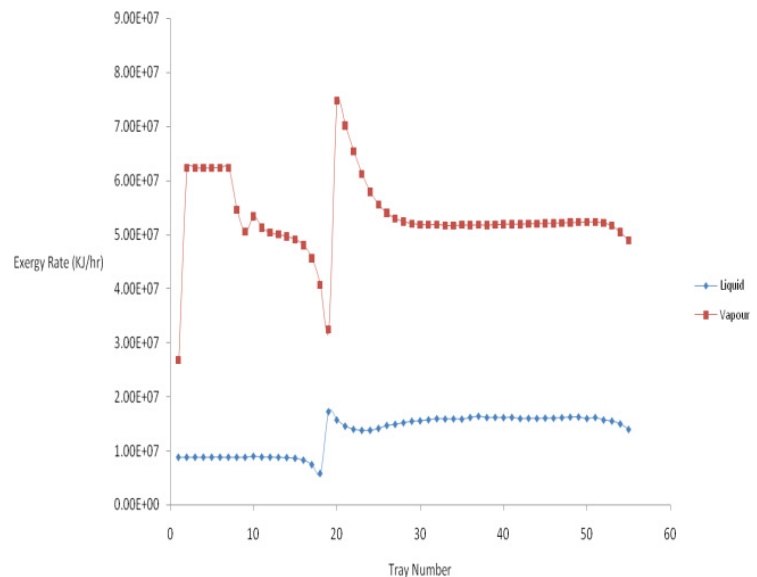

Figure 11. Profile of exergy rate versus tray number for Depropanizer of base case, $80 \mathrm{oC}$

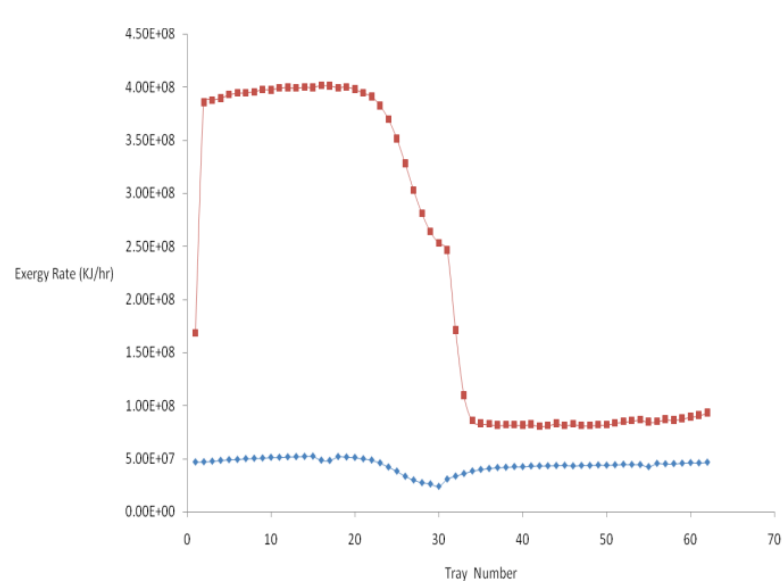

Figure 12. Profile of exergy rate versus tray number for Depropanizer of base case, $80^{\circ} \mathrm{C}$

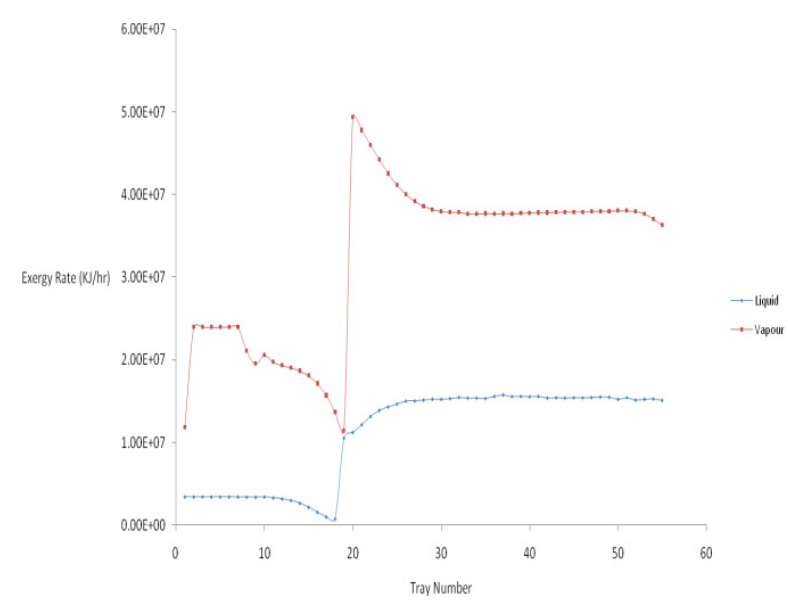

Figure 13. Profile of exergy rate versus tray number for Depropanizer of base case, $30^{\circ} \mathrm{C}$, Reflux Ratio 2

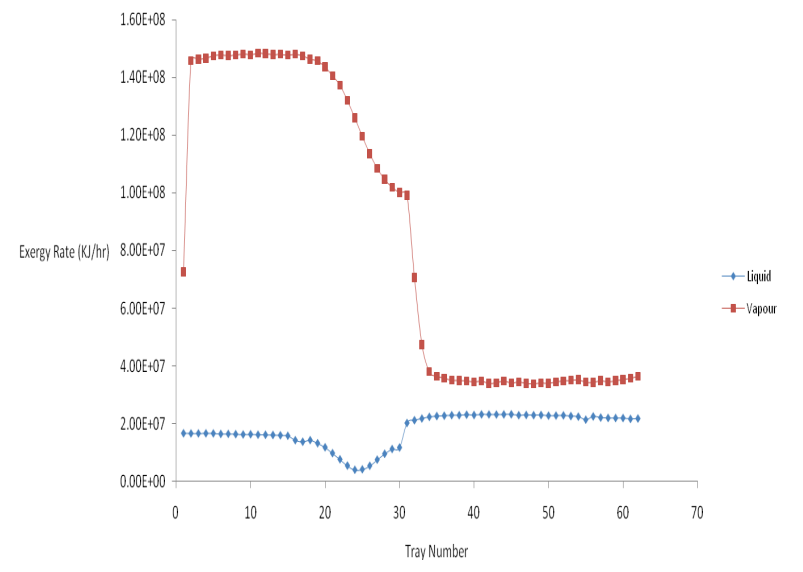

Figure 14. Profile of exergy rate versus tray number for Debutanizer of base case, $30^{\circ} \mathrm{C}$, Reflux Ratio 2

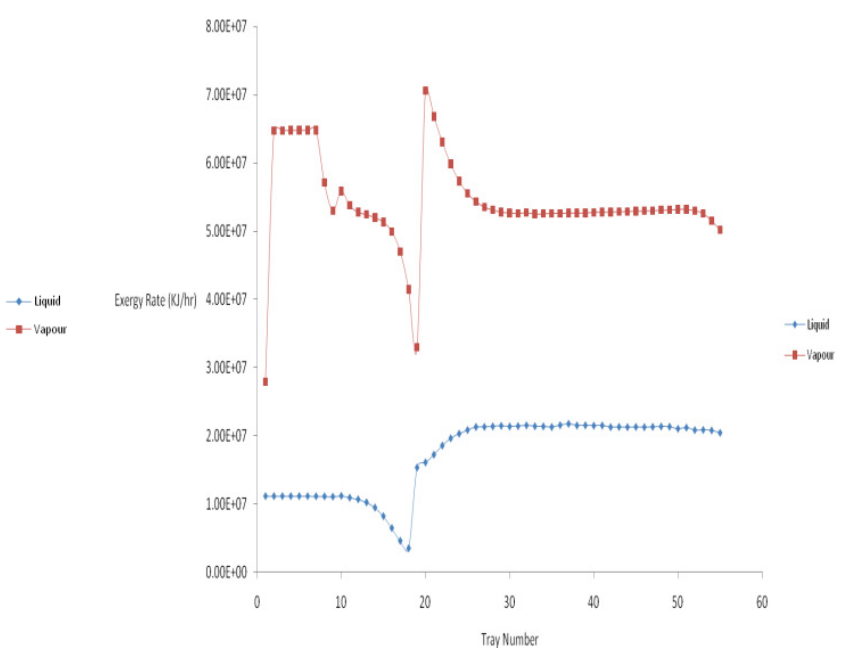

Figure 15. Profile of exergy rate versus tray number for Depropanizer of base case, $30^{\circ} \mathrm{C}$, Reflux Ratio 6

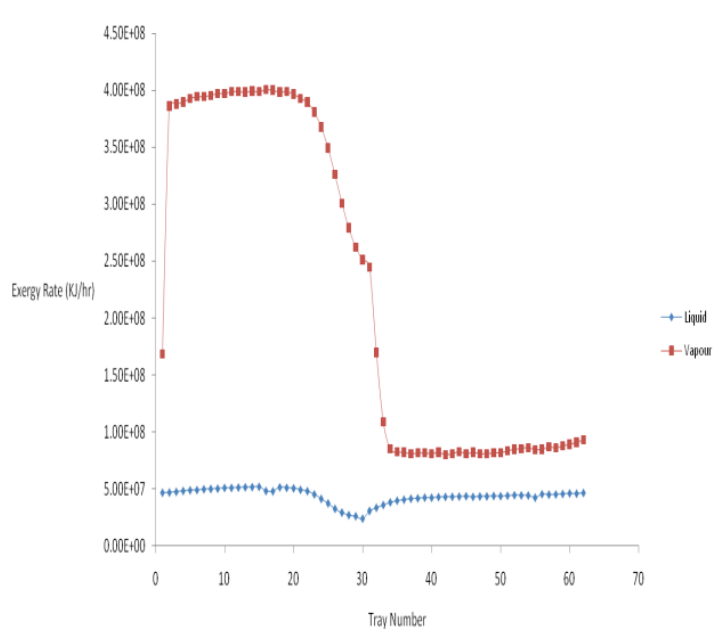

Figure 16. Profile of exergy rate versus tray number for Depropanizer of base case, $30^{\circ} \mathrm{C}$, Reflux Ratio 6 
PAPER

EXergy RAte Profile of Multicomponent Distillation System

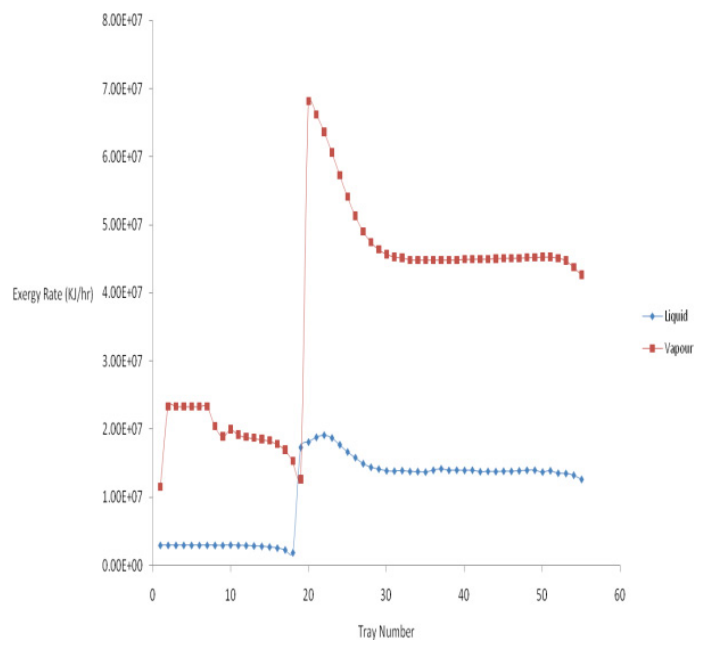

Figure 17. Profile of exergy rate versus tray number for Depropanizer of base case, $80^{\circ} \mathrm{C}$, Reflux Ratio 2

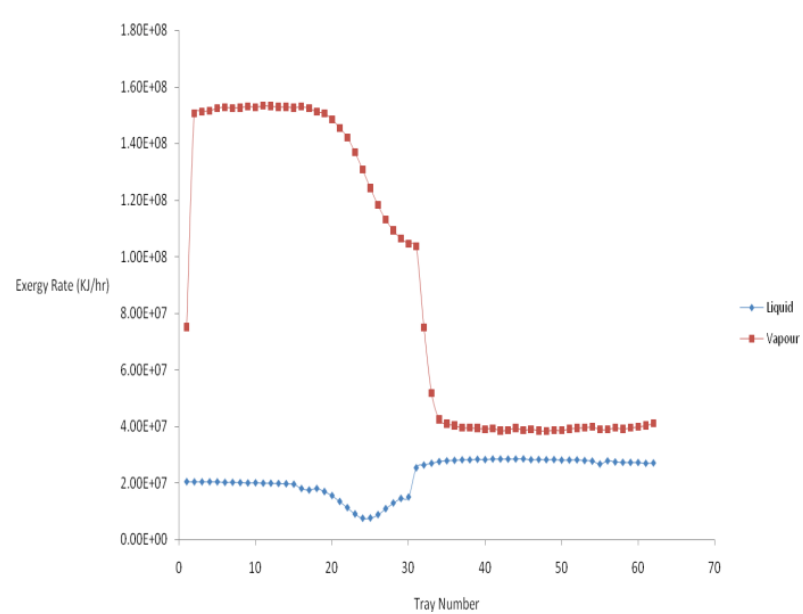

Figure 18. Profile of exergy rate versus tray number for Debutanizer of base case, $80^{\circ} \mathrm{C}$, Reflux Ratio 2

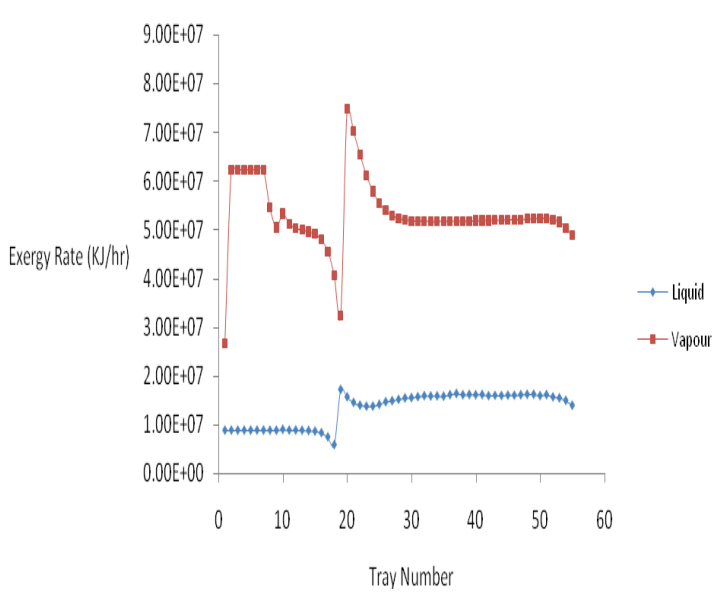

Figure 19. Profile of exergy rate versus tray number for Depropanizer of base case, $80^{\circ} \mathrm{C}$, Reflux Ratio 6

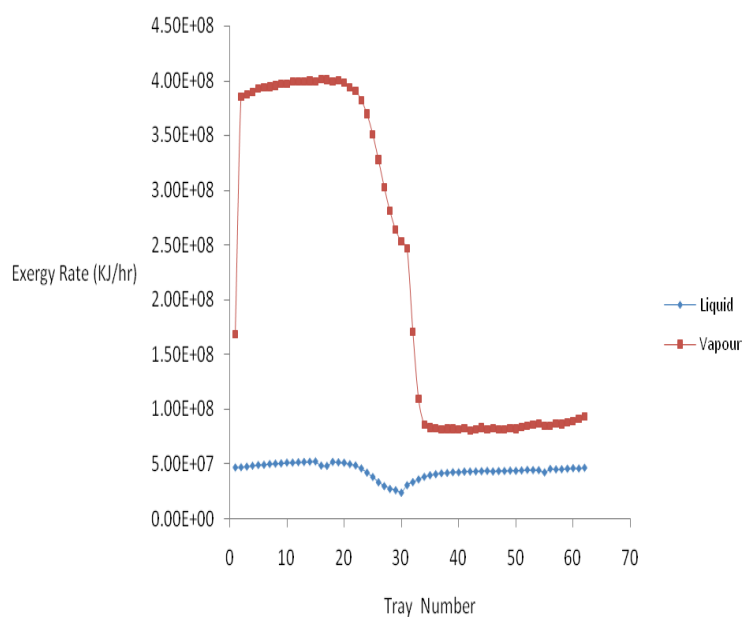

Figure 20. Profile of exergy rate versus tray number for Debutanizer of base case, $80^{\circ} \mathrm{C}$, Reflux Ratio 6

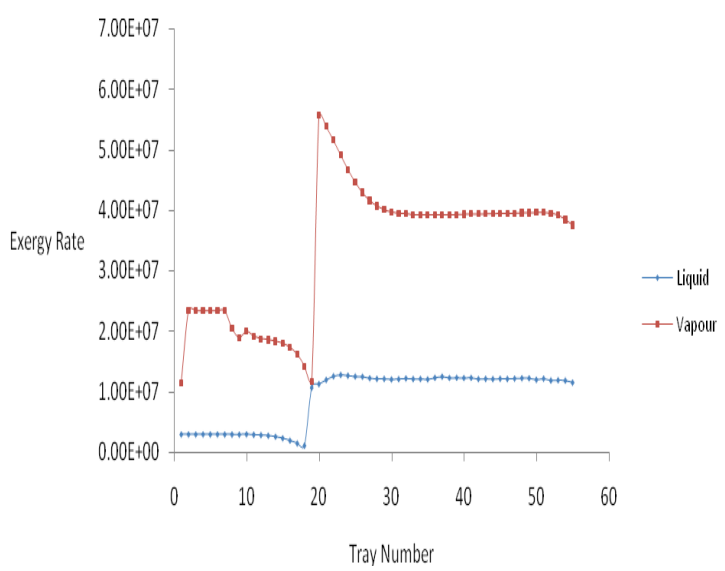

Figure 21. Profile of exergy rate versus tray number for Depropanizer of base case, Reflux Ratio 2

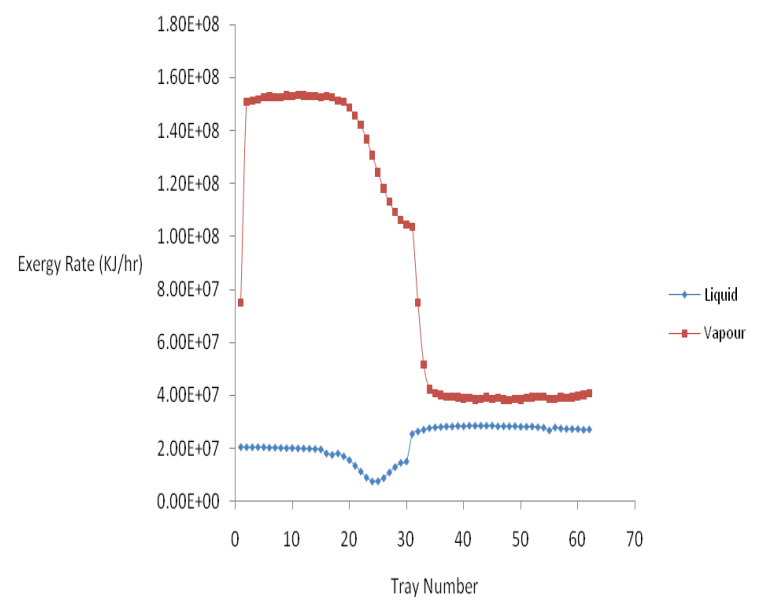

Figure 22. Profile of exergy rate versus tray number for Debutanizer of base case Reflux Ratio 2 
PAPER

EXergy RAte Profile of Multicomponent Distillation System

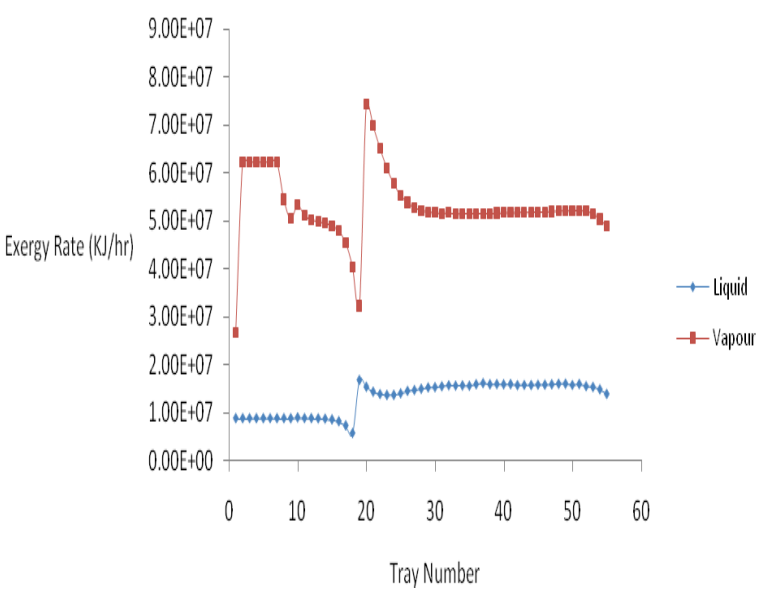

Figure 23. Profile of exergy rate versus tray number for Depropanizer of base case, Reflux Ratio 6

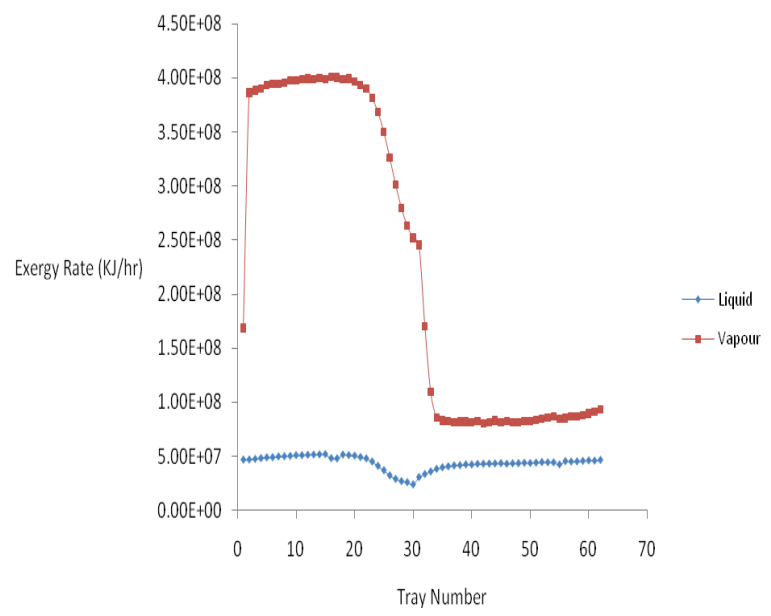

Figure 24. Profile of exergy rate versus tray number for Depropanizer of base case, Reflux Ratio 6

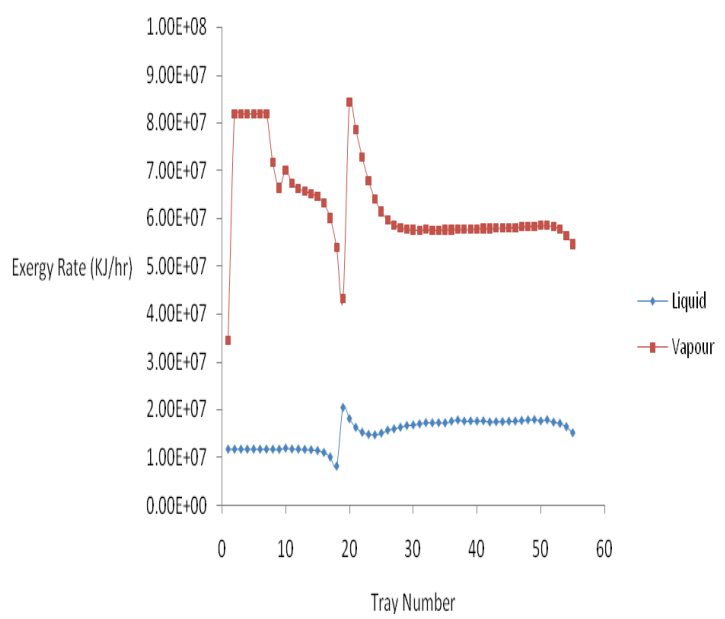

Figure 25. Profile of exergy rate versus tray number for Depropanizer of base $1200 \mathrm{KPa}$ Case

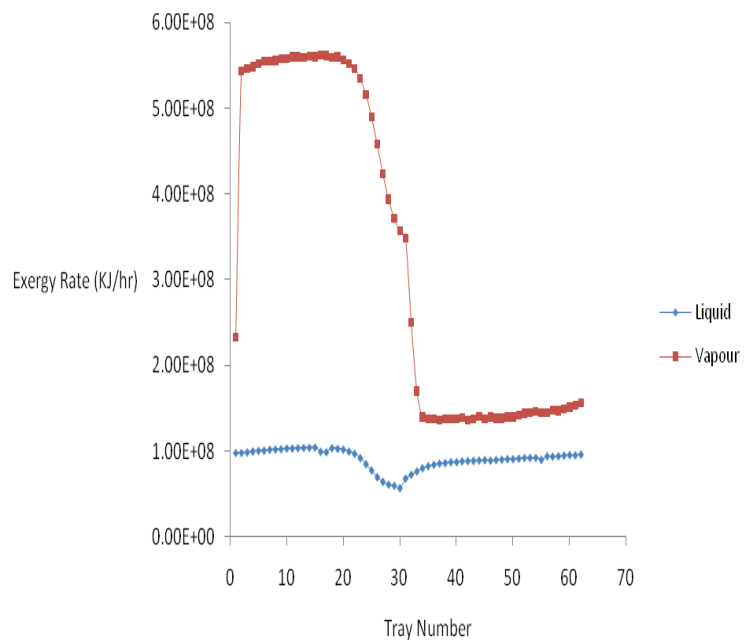

Figure 26. Profile of exergy rate versus tray number for Debutanizer of base $1200 \mathrm{KPa}$ Case

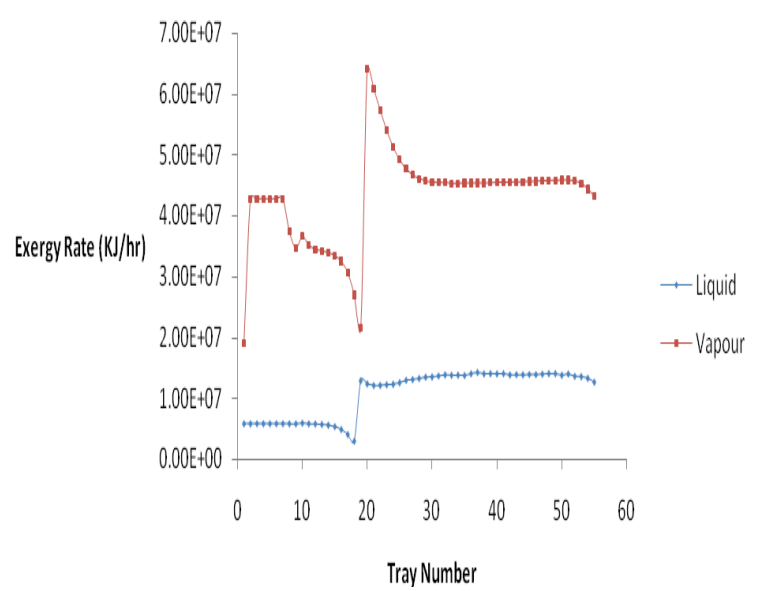

Figure 27. Profile of exergy rate versus tray number for Depropanizer of base $800 \mathrm{KPa}$ case

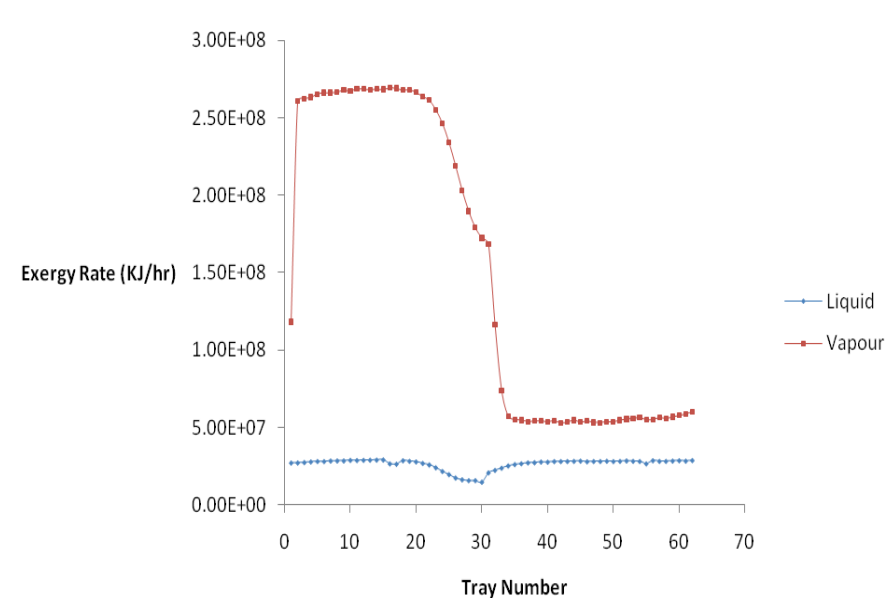

Figure 28. Profile of exergy rate versus tray number for Debutanizer of base $800 \mathrm{KPa}$ case 
TABLE I.

COLUMNS AND SYSTEMS EXERGETIC EFFICIENCY FOR FEASIBLE DESIGN CASES

\begin{tabular}{|c|c|c|c|c|}
\hline \multirow{2}{*}{\multicolumn{2}{|c|}{$\begin{array}{l}\text { Design Process Condi- } \\
\text { tions }\end{array}$}} & \multicolumn{3}{|c|}{ Exergy Efficiency (\%) } \\
\hline & & Depropanizer & Debutanizer & System \\
\hline $\begin{array}{l}\text { Base Case } \\
1000 \mathrm{Kpa}, \mathrm{RR} 4)\end{array}$ & $\left(-50^{\circ} \mathrm{C}\right.$ & 81.70 & 65.20 & 58.72 \\
\hline $\begin{array}{l}\text { Base } \quad \text { Case } \\
\text { 1000Kpa, RR4) }\end{array}$ & $\left(-30^{\circ} \mathrm{C}\right.$ & 70.00 & 54.90 & 95.70 \\
\hline $\begin{array}{l}\text { Base } \quad \text { Case } \\
1000 \mathrm{Kpa}, \mathrm{RR} 4)\end{array}$ & $\left(-80^{\circ} \mathrm{C}\right.$ & 79.60 & 65.20 & 58.17 \\
\hline $\begin{array}{l}\text { Base Case } \\
1000 \mathrm{Kpa}, \mathrm{RR} 6)\end{array}$ & $\left(-30^{\circ} \mathrm{C}\right.$ & 66.80 & 61.30 & 79.98 \\
\hline $\begin{array}{l}\text { Base Case } \\
1000 \mathrm{Kpa}, \mathrm{RR} 6)\end{array}$ & $\left(-80^{\circ} \mathrm{C}\right.$ & 57.40 & 61.30 & 75.22 \\
\hline $\begin{array}{l}\text { Base Case } \\
1000 \mathrm{Kpa}, \mathrm{RR} 6)\end{array}$ & $\left(-50^{\circ} \mathrm{C}\right.$ & 63.00 & 61.30 & 78.16 \\
\hline $\begin{array}{l}1200 \mathrm{KPa} \quad\left(-50^{\circ} \mathrm{C},\right. \\
\text { Case }\end{array}$ & RR4) & 0.66 & 0.65 & 89.18 \\
\hline $\begin{array}{l}800 \mathrm{KPa} \quad\left(-50^{\circ} \mathrm{C},\right. \\
\text { Case }\end{array}$ & RR4) & 82.10 & 65.20 & 59.50 \\
\hline $\begin{array}{l}\text { Splitted Feed Case ( } \\
\text { 1000Kpa, RR4) }\end{array}$ & $\left(-50^{\circ} \mathrm{C}\right.$ & 81.70 & 65.20 & 58.72 \\
\hline $\begin{array}{l}\text { Splitted Feed Case ( } \\
\text { 1000Kpa, RR4) }\end{array}$ & $\left(-30^{\circ} \mathrm{C}\right.$ & 81.70 & 65.20 & 97.99 \\
\hline
\end{tabular}

TABLE II.

COLUMNS AND SYSTEMS IRREVERSIBILITY FOR FEASIBLE DESIGN CASES

\begin{tabular}{|c|c|c|c|}
\hline \multirow{2}{*}{$\begin{array}{|ll|}\text { Design } & \text { Process } \\
\text { Conditions } & \end{array}$} & \multicolumn{3}{|c|}{ Irreversibility (KJ/hr) } \\
\hline & Depropanizer & Debutanizer & System \\
\hline $\begin{array}{l}\text { Base Case }\left(-50^{\circ} \mathrm{C},\right. \\
1000 \mathrm{Kpa}, \mathrm{RR} 4)\end{array}$ & $1.05 \mathrm{E}+7$ & $2.54 \mathrm{E}+7$ & $3.58 \mathrm{E}+7$ \\
\hline \begin{tabular}{|l|} 
Base Case $\left(-30^{\circ} \mathrm{C}\right.$, \\
$1000 \mathrm{Kpa}, \mathrm{RR} 4)$
\end{tabular} & $7.78 \mathrm{E}+6$ & $2.49 \mathrm{E}+7$ & $1.51 \mathrm{E}+6$ \\
\hline \begin{tabular}{|l|} 
Base Case $\left(-80^{\circ} \mathrm{C}\right.$, \\
$1000 \mathrm{Kpa}, \mathrm{RR} 4)$
\end{tabular} & $1.23 \mathrm{E}+7$ & $2.54 \mathrm{E}+7$ & $3.76 \mathrm{E}+7$ \\
\hline $\begin{array}{l}\text { Base Case }\left(-30^{\circ} \mathrm{C},\right. \\
1000 \mathrm{Kpa}, \mathrm{RR} 6)\end{array}$ & $9.08 \mathrm{E}+6$ & $3.33 \mathrm{E}+7$ & $4.41 \mathrm{E}+7$ \\
\hline \begin{tabular}{|l|} 
Base Case $\left(-80^{\circ} \mathrm{C}\right.$, \\
$1000 \mathrm{Kpa}, \mathrm{RR} 6)$
\end{tabular} & $1.36 \mathrm{E}+7$ & $3.33 \mathrm{E}+7$ & $4.38 \mathrm{E}+7$ \\
\hline $\begin{array}{l}\text { Base Case }\left(-50^{\circ} \mathrm{C},\right. \\
1000 \mathrm{Kpa}, \mathrm{RR} 6)\end{array}$ & $1.07 \mathrm{E}+7$ & $3.33 \mathrm{E}+7$ & $1.58 \mathrm{E}+7$ \\
\hline $\begin{array}{ll}1200 \mathrm{KPa} & \left(-50^{\circ} \mathrm{C},\right. \\
\text { RR4) Case } & \end{array}$ & $9.10 \mathrm{E}+6$ & $2.54 \mathrm{E}+7$ & $6.17 \mathrm{E}+6$ \\
\hline $\begin{array}{|ll|}800 \mathrm{KPa} & \left(-50^{\circ} \mathrm{C},\right. \\
\text { RR4) Case } & \\
\end{array}$ & $1.05 \mathrm{E}+7$ & $2.54 \mathrm{E}+7$ & $3.59 \mathrm{E}+7$ \\
\hline $\begin{array}{ll}\text { Splitted } & \text { Feed Case }(- \\
50^{\circ} \mathrm{C}, & 1000 \mathrm{Kpa}, \\
\mathrm{RR} 4) & \\
\end{array}$ & $1.05 \mathrm{E}+7$ & $2.54 \mathrm{E}+7$ & $3.58 \mathrm{E}+7$ \\
\hline $\begin{array}{|lr|}\text { Splitted } & \text { Feed Case }(- \\
30^{\circ} \mathrm{C}, & 1000 \mathrm{Kpa}, \\
\text { RR4) } & \\
\end{array}$ & $7.79 \mathrm{E}+6$ & $2.16 \mathrm{E}+7$ & $1.12 \mathrm{e}+6$ \\
\hline
\end{tabular}

\section{CONCLUSION AND RECOMMENDTIONS}

The use of exergy analysis in improving the operation of multicomponent distillation from the dimension of exergy rate diagram has been emphasised. There is need to optimize the examined feasible operating condition ranges and also determine columns exergy loss distribution profiles in order to determine the optimum condition of operating this multicomponent distillation system. There are great potentials of applying exergy rate diagrams to other chemical processes.

\section{REFERENCES}

[1] Alatiqi, I.M. and Luyben, W.L Alternative distillation configurations for separating ternary mixtures with small concentration of intermediate in the feed, Ind Eng Chem Process Des Dev, 24 500-506, 1985. http://dx.doi.org/10.1021/i200029a047

[2] Al-Muslim H., and Dincer I. Thermodynamic analysis of crude oil distillation systems, International Journal of Energy Research, 29, 2005, 637. http://dx.doi.org/10.1002/er.1097

[3] Blancarte-Palacios, J.L., Bautista-Valde's, M.N., Herna'ndez, S., Rico-Ramı'rez, V. and Jime'nez, A. Energy- efficient designs of thermally coupled distillation sequences for four- component mixtures, Ind Eng Chem Res, 21, 5157-5164, 2003. http://dx.doi.org/10.1021/ie030297k

[4] Christiansen, A.C., Skogestad, S. and Lien, K.. Complex distillation arrangements: extending the Petlyuk idea, Comput Chem Eng, 21, 1997, S237-S242, 1997.

[5] Demirel, Y. Retrofit of distillation columns using thermodynamic analysis. Separation Sciences and Technology, 41, 791- 817, 2006. http://dx.doi.org/10.1080/01496390600600047

[6] Dhole V.R., and Linnhoff B. Distillation Column Targets, Computers and Chemical Engineering 17, 1993, 549-560, 199.

[7] Engelien HK, Larsson T, and Skogestad S. Implementation of Optimal Operation for Heat Integrated Distillation Columns, TransInst Chem Eng;81, 277-81, 2003.. http://dx.doi.org/10.1205/026387603762878755

[8] Faria, S.H.B., and Zemp, R. J. Using exergy loss profiles and enthalpy-temperature profiles for the evaluation of thermodynamic efficiency in distillation columns, J. Thermal Engineering, Vol. 4, No. 4, $76-82,2005$.

[9] Flores, O. A., Cardenas, C., Hernandez, S., and RicoRamyrez, V. Thermodynamic Analysis of Thermally Coupled Distillation Sequences, Ind. Eng. Chem. Res., 42, 5940, 2003. http://dx.doi.org/10.1021/ie034011n

[10] Finn, A.J. Consider thermally coupled distillation, Chem Eng Prog, 10, 41-45, 1993.

[11] Fidkowski, Z. and Krolikowski, L. Energy requirements of nonconventional distillation systems, AIChE J, 36, 1275-1278, 1990. http://dx.doi.org/10.1002/aic.690360820

[12] Glinos, K. and Malone, F. Optimality regions for complex column alternatives in distillation systems, Trans IChemE, PartA, Chem Eng Res Des., 66, 229-240, 1998.

[13] Herna'ndez, S. and Jime'nez, A. Design of optimal thermallycoupled distillation systems using a dynamic model, Trans IChemE, Part A, Chem Eng Res Des., 74, 357-362, 1996.

[14] Hsuan, C., and Jr-Wie, L., A new exergy method for process analysis and optimization, Chemical Engineering Science., 60, 2771, 2005. http://dx.doi.org/10.1016/j.ces.2004.12.029

[15] King, C.J., Separation Processes (McGraw-Hill, New York, $2^{\text {nd }}$ edition,), 1980.

[16] [16] Le Goff, P., and Hornut, J.M. Exergy analysis and exergoeconomic optimization of industrial process (Janvier-Fevrier,), 1998.

[17] Le Goff, P., Cachot, T. and Rivero, R. Exergy analysis of distillation process. Chemical Engineering and Technology, Vol.19, 478 - 485, 1996. http://dx.doi.org/10.1002/ceat.270190603

[18] Maia M. L. O., Zemp R.J. Thermodynamic analysis of multicomponent distillation columns: identifying optimal feed conditions, Brazilian Journal of Chemical Engineering, vol 17, 751-759, 2000. http://dx.doi.org/10.1590/S0104-66322000000400038

[19] Olujic, Z., Fakhri, F., De Rijke, A., De Graauw J., and Jansens, P.J. Internal heat integration - the key to an energy-conserving distillation column., Journal of Chemical Technology and Biotechnology. 78, 241, 2003. http://dx.doi.org/10.1002/jctb.761

[20] Rivero, R., and Koeijer, G. Entropy production and exergy loss in experimental distillation columns, Chemical Engineering Science, 58, 1587, 2003. http://dx.doi.org/10.1016/S0009-2509(02)00627-9

[21] Rong, B., Kraslawski, A., and Nystrom, L. The synthesis f thermally coupled distillation flowsheets for separations of five component mixture, Computers Chem. Engng., 24, 247 - 252, 2000. http://dx.doi.org/10.1016/S0098-1354(00)00466-X

[22] Ruchira, T., and Masaru, I. Graphical exergy analysis of processes in distillation column by energy utilization diagrams. AIChE 
PAPER

EXERGy RATE Profile of MulticomPonent Distillation System

$\begin{array}{llllll}\text { Journal, } \quad \text { Vol. } \quad 42, \quad \text { No } \quad 6, \quad 1633- & 1641,1996 .\end{array}$ http://dx.doi.org/10.1002/aic.690420615

[23] Tedder, D.W. and Rudd, D.F. Parametric studies in industrial distillation: Part I. Design comparisons. AIChE J, 24:303-315, 1978. http://dx.doi.org/10.1002/aic.690240220

[24] Smith R., and Zemp R.J. Process integration of separation systems, in: Separation Technology: the next ten years (IChemE, UK,), 1994.

[25] Santanu, B. Effect of feed on optimal thermodynamic performance of a distillation column. Chemical Engineering Journal, Vol. 88. 175-186, 2002. http://dx.doi.org/10.1016/S13858947(01)00303-5

[26] Taprap, R., and Ishida, M. Graphic exergy analysis of processes in distillation column by energy-utilization diagrams, AIChE $\begin{array}{llllll}\text { Journal, } & \text { Vol. } & 42, & \text { No. 6, 1633, } 1996 .\end{array}$ http://dx.doi.org/10.1002/aic.690420615

[27] Zemp R.J., de Faria S.H.B, Maia M.L.O. Driving force distribution and exergy loss in the thermodynamic analysis of distillation columns, Computers and Chemical Engineering, Vol 21S, S523 S528, 1997. http://dx.doi.org/10.1016/S0098-1354(97)00102-6

\section{AUTHORS}

K. Adewale Adesina is a research scholar at Eastern Mediterranean University where he is undergoing $\mathrm{PhD}$ in Industrial Engineering. Basically his area of research includes simulation, modeling, design of experiments, data envelopment, engineering quality control and reliability. Currently, he is applying neural network and modified data envelopment model to solve multi-response problem of Taguchi robust parameter procedures. He is a COREN Registered Chemical Engineer and a Lecturer at the Department of Food Science and Technology, Rufus Giwa Polytechnic, Owo (e-mail: adexkwale@yahoo.com).

C. Abiodun Popoola is a Registered Chemical Engineer and Lecturer in the Department of Food Science and Technology, Federal University Wukari, Taraba. He is currently pursuing $\mathrm{PhD}$ in Production Engineering in University of Agriculture, Makurdi, Nigeria. His research area is development of machines and equipment (Email:calebiodunchem@yahoo.com).

Submitted 01 April 2016. Published as resubmitted by the authors 30 May 2016. 